\title{
The Neoproterozoic Rivieradal Group of Kronprins Christian Land, eastern North Greenland
}

\author{
M. Paul Smith, A.K. Higgins, N.J. Soper and Martin Sønderholm
}

\begin{abstract}
The Rivieradal Group, formally defined here, is confined to the Vandredalen thrust sheet of the Caledonian orogen in Kronprins Christian Land, eastern North Greenland. It comprises a succession of Neoproterozoic siliciclastic sediments that represent the fill of a half-graben basin. The syn-rift Rivieradal Group is overlain by post-rift sediments of the Hagen Fjord Group. The latter succession is present in both the thrust sheet and the Caledonian foreland to the west. In the foreland, where the Rivieradal Group is not represented, the Hagen Fjord Group disconformably overlies Palaeoproterozoic-Mesoproterozoic sandstones of the Independence Fjord Group.
\end{abstract}

Keywords: Caledonian, North Greenland, Precambrian, Proterozoic, stratigraphy

\begin{abstract}
M.P.S., Lapworth Museum, School of Geography, Earth and Environmental Sciences, University of Birmingham, Edgbaston, Birmingham B15 2TT, UK. E-mail: m.p.smith@bham.ac.uk

A.K.H. \& M.S., Geological Survey of Denmark and Greenland, Øster Voldgade 10, DK-1350, Copenhagen K, Denmark.

N.J.S., Gams Bank, Threshfield, Skipton BD23 5NP, UK. Also affiliated with: Department of Geology, University College, Galway, Ireland.
\end{abstract}

Kronprins Christian Land lies at the northern termination of the East Greenland Caledonides, and constitutes a key area for studies of the western border zone of the orogen (Fig. 1). This region exposes continuous sections from the undisturbed foreland in the west, across parautochthonous foreland affected by folding and thin-skinned thrusting to allochthonous thrust sheets in the east (Higgins et al. 2001a, b). The foreland comprises three principal lithostratigraphical divisions: (1) Palaeoproterozoic-Mesoproterozoic sandstones of the Independence Fjord Group, the Mesoproterozoic Zig-Zag Dal Basalt Formation and associated dolerites (Midsommersø Dolerite Formation); (2) Neoproterozoic shallow marine sediments of the Hagen Fjord Group (Sønderholm \& Jepsen 1991); (3) Cambrian-Silurian shelf sediments of the Franklinian Basin (Higgins et al. 1991). The Hagen Fjord Group is also represented within the allochthon, in the Vandredalen thrust sheet, where it overlies the clastic sedi- ments of the Rivieradal Group, which are the subject of this paper.

In Kronprins Christian Land the parautochthonous Lower Palaeozoic sediments lie in the foot wall of the Vandredalen thrust sheet, and are deformed by a series of thin-skinned thrusts that constitute a duplex below the Vandredalen thrust (Figs 1, 2). This parautochthonous area extends as a 30-50 km wide belt to the west of the $200 \mathrm{~km}$ long, N-S-trending Vandredalen thrust front. The Vandredalen thrust displays a classical staircase trajectory with very long $(20+\mathrm{km})$ flats developed in dolomitic horizons, and ramps developed in the more resistant subtidal carbonate units of the Franklinian Basin succession (cf. Smith et al. 2004, this volume). The thrust roots to the east along the Spærregletscher - Hekla Sund lineament and has a total westward displacement estimated at $c .40 \mathrm{~km}$, of which $c .18 \mathrm{~km}$ are taken up in the thin-skinned parautochthonous belt (Higgins et al. 2001b, 2004). The 


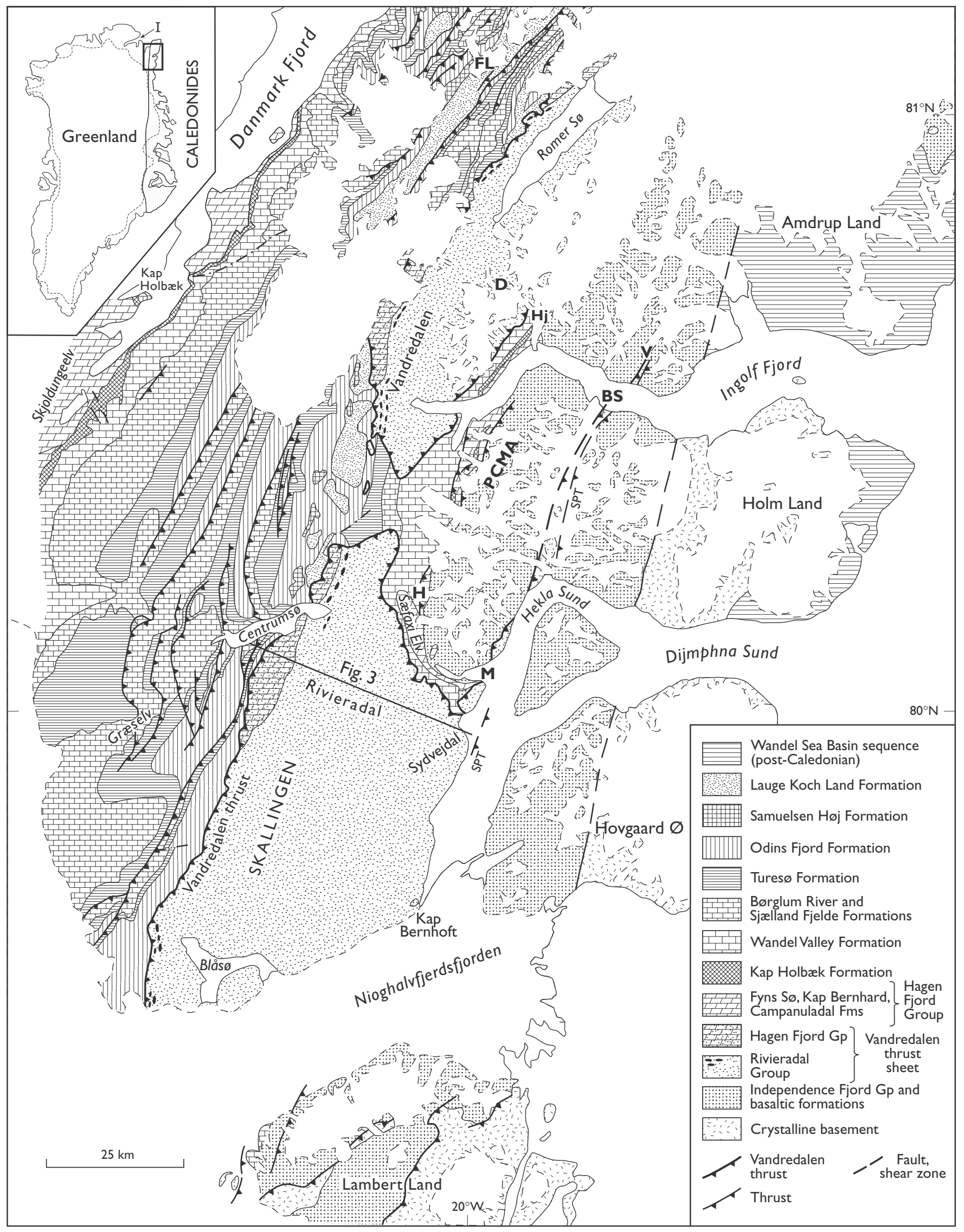


Vandredalen thrust sheet, in turn, is structurally overlain by a thrust sheet that transported Palaeoproterozoic to Mesoproterozoic clastic and volcanic rocks westwards. The allochthonous quartzites have traditionally been viewed as equivalents of the Independence Fjord Group on the foreland (see Figs 1, 2), but SHRIMP isotopic studies on rhyolites interbedded with the quartzites that yielded an age of $1740 \mathrm{Ma}$ (Kalsbeek et al. 1999) have cast some doubt on this interpretation (see also Pedersen et al. 2002). Still farther to the east, higher thick-skinned thrust sheets incorporate crystalline basement gneisses.

This paper provides a formal stratigraphic basis, at group level, for the rocks that underlie the Hagen Fjord Group within the Vandredalen thrust sheet, and collates available field data regarding this succession. As noted below, formal definition of the constituent formations awaits more detailed field analysis of the Rivieradal Group. The informal units of Fränkl (1954, 1955) were found to be generally usable as field divisions, although there is uncertainty in places about their correlation.

\section{Stratigraphy of the Vandredalen thrust sheet}

Restoration of the displacement associated with the Vandredalen thrust sheet demonstrates that much of the sediment within the thrust sheet was deposited in an east-facing extensional half-graben (Hekla Sund basin) that originally lay immediately to the east of the Spærregletscher - Hekla Sund lineament (Higgins et al. 2001b). This basin fill was thrust out of the halfgraben and transported westwards on the Vandreda-

\section{Facing page:}

Fig. 1. Geological map of Kronprins Christian Land, eastern North Greenland, and Lambert Land, North-East Greenland. Black oval symbols in the Rivieradal Group, in legend and on map, indicate conglomerates. BS, Brede Spærregletscher; D, 'Dunkeldal'; FL, Finderup Land; H, Harefjeld; Hj, Hjørnegletscher; M, Marmorvigen; PCMA, Prinsesse Caroline Mathilde Alper; SPT, Spærregletscher thrust; V, Vardedalen. On index map: I, Independence Fjord. See Figs 2 and 3 for cross-sections along Rivieradal. Modified from Rasmussen \& Smith (2001). Note that the traditional interpretation of the allochthonous quartzites as equivalents of the foreland Independence Fjord Group (as depicted here and on Fig. 2), has been brought into doubt by the $1740 \mathrm{Ma}$ age on interbedded rhyolites (see discussion in Kalsbeek et al. 1999 and Pedersen et al. 2002). len thrust (Fig. 2). These syn-rift sediments are assigned to the Rivieradal Group, which is formally erected below. They are overlain by sediments of the Hagen Fjord Group, which were deposited during postrift thermal subsidence and extended westwards beyond the confines of the Hekla Sund basin. The Hagen Fjord Group, in consequence, is present both in the foreland and the hanging wall of the Vandredalen thrust whereas the Rivieradal Group is restricted to the hanging wall (Higgins et al. 2001b). The Hagen Fjord Group within the Vandredalen thrust sheet is represented by the Campanuladal, Kap Bernhard and Fyns S $\varnothing$ Formations. The Campanuladal Formation comprises $200 \mathrm{~m}$ of variegated sandstones, siltstones and mudstones of generally similar appearance to successions of the same unit in the foreland around Danmark Fjord. A lower, greenish weathering unit containing parallel and trough cross-laminated sandstones, and mudstones with desiccation cracks, is overlain by an upper, dark red weathering unit dominated by calcareous mudstones with some trough cross-bedded sandstones (Jepsen \& Sønderholm 1994). The Kap Bernhard Formation comprises brownish red weathering, finely laminated algal limestones and the Fyns Sø Formation contains pale stromatolitic dolostones; both correspond very closely to their counterparts in the foreland.

In the northernmost part of the outcrop area of the Vandredalen thrust sheet, in Finderup Land (Fig. 1), the Fyns Sø Formation is unconformably overlain by sandstones of the Kap Holbak Formation. This latter unit was included within the redefined Hagen Fjord Group of Clemmensen \& Jepsen (1992), but stratigraphic data obtained during the 1994-1995 field seasons demonstrated that a significant hiatus occurs between the two units. In particular, a well-developed palaeokarst horizon developed at the top of the Fyns Sø Formation is infilled by the Kap Holbæk Formation (Smith et al. 1999). It is probable that the carbonates of the Fyns $\mathrm{S} \varnothing$ Formation are correlatives of similar late Riphean to Sturtian units, which are widely developed in the North Atlantic region, while the presence of deep Skolithos burrows in the Kap Holbæk Formation indicates a Lower Cambrian age (Smith et al. 2004, this volume). Since the hiatus between the two units probably spans the entire Vendian, Smith et al. (2004) proposed that the Kap Holbæk Formation be removed from the Hagen Fjord Group. 

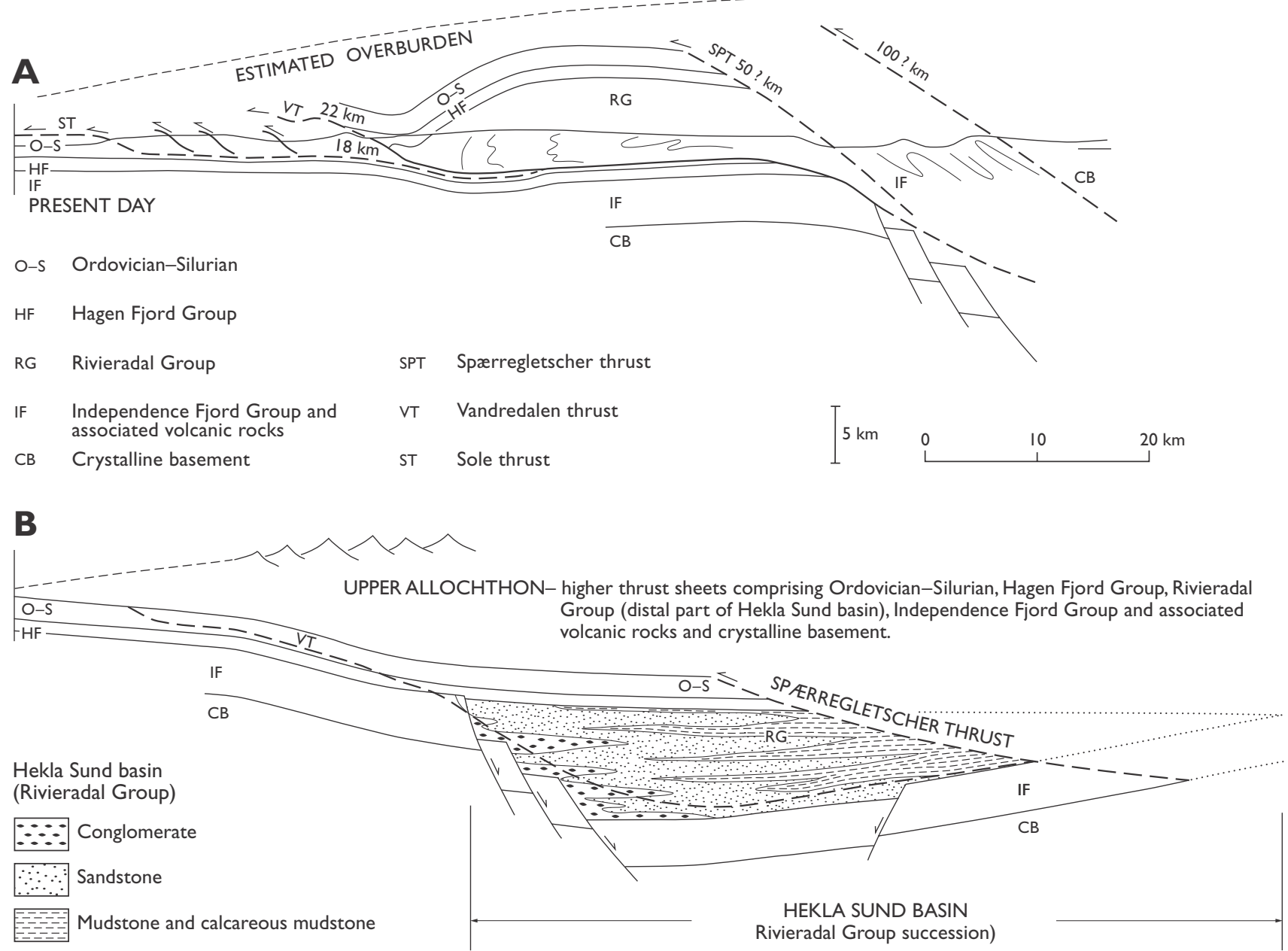

Fig. 2. Schematic NW-SE cross-sections of the Vandredalen rift system, approximately along the section line of Fig. 3 shown on Fig. 1, but with extensions to both south-east and north-west. A: Present-day section, with overburden calculated from conodont alteration temperatures (after Rasmussen \& Smith 2001). B: With displacements on the thrusts restored, illustrating the fault-bounded control of the west margin of the Hekla Sund Basin. Modified from Higgins et al. (2001b).

\section{Rivieradal Group}

new group

History. The Proterozoic rocks of Kronprins Christian Land were first examined systematically by geologists of Lauge Koch's 1926-1958 expeditions. The region around Danmark Fjord was documented by Adams \& Cowie (1953), and that around Centrums $\varnothing$ by Fränkl (1954, 1955). Fränkl recognised that the Neoproterozoic succession could be divided into autochthonous and allochthonous parts, the two separated by a major thrust upon which his 'main nappe' was transported. The metasediments of the nappe were divided into a lower, more metamorphosed part, comprising the
Stenørkenen Phyllites (> $1000 \mathrm{~m}$ ) and the Sydvejdal Marbles (100-400 m), and an upper less metamorphic part. The latter included, from base to top, the Taagefjeldene Greywackes (> $700 \mathrm{~m}$ ) with a layer of alum shales at the base (c. $150 \mathrm{~m})$, the Rivieradal Sandstones (1000-2000 m), the Ulvebjerg Sandstones \& Tillites (20-35 m), the red, shaly Campanuladal Limestone and the Fyns Sø Formation. The two last-named units were also identified as lying in the foot wall of the nappe (Fränkl 1954, 1955). The succession present in the 'main nappe' was recognised as having been deposited in a basin located to the east, which Fränkl (1955) termed the 'Hekla Sund Basin'; the latter term is retained here for the depositional basin in which the Rivieradal Group accumulated. 
Haller (1961, 1971) erected the Hagen Fjord Group for Proterozoic sediments of the autochthon and allochthon in Kronprins Christian Land, including volcanic rocks now referred to the Zig-Zag Dal Basalt Formation, Hekla Sund Formation and Aage Berthelsen Gletscher Formation, and Lower Cambrian carbonates now referred to the Portfjeld Formation. Clemmensen \& Jepsen (1992) restricted the group, following work by the Geological Survey of Greenland in 1978-1980, to include only the Neoproterozoic shallow water carbonate and siliciclastic succession present in the area between Lambert Land and Independence Fjord. Additional formations were also erected by Clemmensen \& Jepsen, to improve the stratigraphical framework of the group.

Hurst \& McKerrow (1981a, b), on the basis of reconnaissance field work in Kronprins Christian Land in 1980 by the former Geological Survey of Greenland (GGU), concluded that all of the units beneath the Campanuladal Formation within the main thrust sheet were representative of a single unit of deepwater turbidites, mud and resedimented conglomerates; they collectively referred to this succession as the 'Rivieradal sandstones'. Although sedimentological interpretations of the succession have been refined (see below), this is the concept that we here formalise as the Rivieradal Group.

Hurst \& McKerrow (1981a, b) and Hurst et al. (1985) recognised a number of thrust sheets in the Kronprins Christian Land sector of the East Greenland Caledonides. These included the Vandredalen Nappe (which corresponds to Fränkl's 'main nappe'), the Finderup Land Nappe and the Sæfaxi Elv Nappe. The Finderup Land Nappe was a geographically isolated structure rimming the western edge of the main ice sheet, and a succession that incorporated the Campanuladal, Fyns Sø and Kap Holbæk Formations was recognised. Subsequent regional mapping by GGU in 1994-1995 has demonstrated that the Finderup Land Nappe is a northward continuation of the Vandredalen Nappe (now the Vandredalen thrust sheet) in which only the higher stratigraphic levels are preserved. The Sxani Elv Nappe was considered by Hurst \& McKerrow to be a thrust sheet containing allochthonous Early Palaeozoic sediments that were deep-water equivalents of the platform succession, and these were assigned to the Harefjeld Formation by Hurst (1984). However, Rasmussen \& Smith (1996) demonstrated that these sediments were highly strained equivalents of the platform succession, and that the lower contact with the underlying Fyns Sø Formation was an unconformity and not a thrust. The 'Sæfaxi Elv Nappe' is thus a succession of parautochthonous foreland carbonates deformed in the foot wall of the Vandredalen thrust, and the concept of an independent thrust sheet (and of the Harefjeld Formation) has been abandoned (Rasmussen \& Smith 1996).

Name. The group takes its name from Rivieradal, the E-W-trending valley south-east of Centrums $\varnothing$ that contains the most complete section through the unit (Higgins \& Soper 1994, 1995).

Type area and reference sections. The type area for the group is Rivieradal itself, where an excellent reference section through the upper part of the group occurs and the lower part, although highly deformed, is also present. Additional reference sections through parts of the group are available through 'Dunkeldal' (between northern Vandredalen and inner Ingolf Fjord; Fig. 1), and along much of the western side of Vandredalen between the western end of Ingolf Fjord and Romer S $\varnothing$.

Thickness. Hurst et al. (1985) estimated a thickness of $2.5 \mathrm{~km}$ for the 'Rivieradal sandstones'. Structural studies in Rivieradal and 'Dunkeldal', carried out during the 1994 and 1995 field seasons, suggest that the combined thickness of the highly deformed lower part of the Rivieradal Group and the less deformed upper part is substantially higher, in the order of $7.5-10 \mathrm{~km}$ (Higgins et al. 2001b).

Lithology, facies associations and depositional environments. The sedimentological and stratigraphical variations within the Rivieradal Group should be viewed in the context of the internal structure of the Vandredalen thrust sheet, which is best exposed in the $35 \mathrm{~km}$ long section along Rivieradal between the thrust sheet front at the east end of Centrums $\varnothing$ and its trailing edge near Marmorvigen (Fig. 3). The western frontal region of the thrust sheet is characterised by simple, large-scale folds developed in the Fyns $\$ \varnothing$ and Kap Bernhard Formations; these overlie the Rivieradal Group sediments, which are well exposed throughout the valley of Rivieradal. Steep to vertical dips characterise much of the western third of the section, with occasional west-facing fold pairs showing flat common limbs. The central third of the section begins with an abrupt change to tightly developed folds, which become progressively more intense eastwards with the inclination of the axial surfaces decreasing 


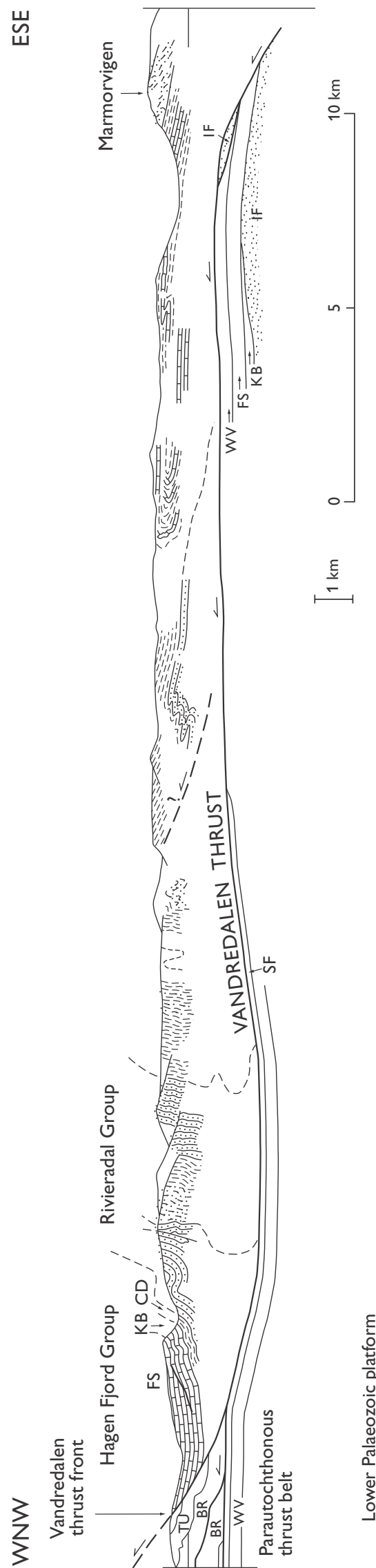

from moderate eastward dips to almost horizontal. In the eastern third of the section deformation is intense with complete erasure of sedimentary way-up indicators in long-limbed isoclinal folds; the units exposed here correspond to the most distal parts of the Rivieradal Group.

The fold style and orientation of strata in the Rivieradal section suggest that the Vandredalen thrust follows a series of ramps and flats, and can be viewed as sampling an oblique segment of the half-graben Hekla Sund Basin in which the Rivieradal Group accumulated. The oldest and most distal parts of the succession are therefore preserved in the eastern part of the thrust sheet, and the younger and more proximal lithofacies are present in the west. The present-day distribution of remnants of the Rivieradal Group succession indicates that the original Hekla Sund Basin must have been at least $200 \mathrm{~km}$ long from north to south and $50 \mathrm{~km}$ wide from east to west.

The Rivieradal Group is lithologically variable and possesses a strong proximal to distal polarity. One of the most distinctive lithologies present is a coarse conglomerate, which occurs repeatedly along the leading edge of the Vandredalen thrust sheet. Substantial conglomerate units are present in three discrete areas (Fig. 1). The northernmost is along a $15-20 \mathrm{~km}$ strike section on the west side of Romer $\$ \varnothing$, the second is a $20 \mathrm{~km}$ long strike section on the west side of central Vandredalen, and the southernmost is found in southern Skallingen near Blås $\varnothing$.

The best known of the conglomeratic successions is that in central Vandredalen where several thick sections have been measured. Quartzite clasts (90-95\%) dominate everywhere over dolerite clasts (5-10\%), and are probably derived from the Independence Fjord Group and the Midsommers $\varnothing$ Dolerite Formation; these units are presumed to have been exposed to active erosion to the west of the basin. Clasts vary in size from a few decimetres to well over a metre in the thicker beds, with occasional outsize clasts as much as 3-4 $\mathrm{m}$ across; these large clasts are indisputably proximal. Viewed from a distance, the thick conglomerate units appear to have a lensoid form, suggesting deposition in a series of nested channels.

In $\mathrm{E}-\mathrm{W}$ valley sections to the west of Romer Sø, rapid lateral facies changes are well exposed. Thick conglomerate-dominated units pass eastwards, over a

Fig. 3. Cross-section through the Vandredalen thrust sheet along Rivieradal. See Fig. 1 for section line. Modified from Higgins et al. (2001b). 
distance of 1-2 km, into upward-thickening packets of sandstone in which the individual beds coarsen upwards, sometimes into conglomerate. These in turn pass farther eastwards, over a similar distance, into upward-thickening and coarsening mudstone-siltstonesandstone packets.

In the southern area of conglomerates near Blås $\varnothing$, rounded granite and quartz pebbles (up to 20\%) make an appearance, although most clasts are again quartzite and dolerite; a deeper erosion level was evidently reached in the southern source region.

The geometry of the conglomerate deposits, together with their discrete occurrences, suggests the presence of three discrete fan delta systems that acted as major feeder distributary systems on the western side of the original basin. While the three main conglomerate developments are all in the upper part of the Rivieradal Group succession, they may not be at exactly the same stratigraphical level. Input might have been via a single major fluvial system, which varied in position with time, and if so the Blåsø fan delta with its crystalline clasts may be the youngest of these. The repeated cycles of conglomeratic deposition, and the upward-coarsening sandstone cycles in other areas at the frontal part of the thrust sheet, may have been controlled by displacements on the basin-margin fault system.

In 'Dunkeldal', a valley on the east side of Vandredalen, a total thickness of $3000 \mathrm{~m}$ has been measured in a continuously exposed section (lower part of measured section in Fig. 4). The basal $200 \mathrm{~m}$ of this section lie above a thrust contact with Ordovician carbonates, and comprise strongly sheared conglomerates. The conglomerates are overlain by a $500 \mathrm{~m}$ thick phyllite-dominated unit ('Stenørkenen Phyllites' of Fränkl 1955), and then by over $2200 \mathrm{~m}$ of sandstone turbidites interbedded with dark pyritic mudstones ('Taagefjeldene Greywackes' of Fränkl). Laterally and vertically, this sandstone-dominated succession grades into homogeneous black mudstones, and equivalent phyllitic rocks, which are widely exposed around the innermost branch of Ingolf Fjord. The lack of marker horizons and non-exposure in the flat valley bottom of Vandredalen makes thickness estimates in these areas difficult; thus the notional gap of $350 \mathrm{~m}$ in the measured section of Fig. 4 may in fact correspond to several kilometres of section.

On the west side of Vandredalen, to the north-west of innermost Ingolf Fjord, a 900 m thick succession comprises coarsening-upwards sequences of parallel laminated mudstone, lenticular and wavy-bedded mudstones, sandstone-dominated heterolithic sediments with parallel lamination, trough cross-lamination and hummocky cross-stratification, overlain by trough and planar cross-bedded sandstones with occasional herringbone cross-bedding (upper part of section in Fig. 4). These correspond to the original 'Rivieradal sandstones' of Fränkl (1955). Current directions are predominantly towards the north-east and are interpreted as the products of storm- and tidedominated shallow marine deposition. This facies association in the upper part of the Rivieradal Group can be recognised throughout the outcrop area, from Romer $S \varnothing$ in the north to Blås $\varnothing$ in the south. On the west side of Vandredalen, the succession of Fig. 4 continues with about $300 \mathrm{~m}$ of interfingering conglomerates and sandstones (the 'Ulvebjerg Sandstones and Tillites' of Fränkl - equivalent to the conglomeratic developments described above), which are overlain by sediments referred to the Hagen Fjord Group. The latter shallow marine succession constitutes the postrift fill of the basin.

The most distal representatives of the Rivieradal Group are seen in the valley of Rivieradal itself. At the eastern end of the valley, pelitic slates with sandstones form the coastal mountains south of the mouth of Rivieradal. These are overlain farther to the west by pelitic and calcareous slates and siltstones with prominent yellow-weathering carbonate units, which correspond to the 'Sydvejdal Marbles with chloritic shales' of Fränkl (1955). This unit is overlain, in turn, by phyllites and turbidites corresponding to those seen in the 'Dunkeldal' section (Fig. 4).

Overall, the Rivieradal Group is characterised by point sources of sediment input which generated substantial conglomerate fan deltas, and which are associated with sandy, proximal turbidites. Between the fans and in the eastern (distal) part of the basin, sedimentation was dominated by mud and calcareous mud. As the basin filled, the depositional style switched from deep to shallow marine, and less localised, more laterally persistent, tidal and storm-dominated deposition began to predominate.

Boundaries. Since the group is restricted to the Vandredalen thrust sheet, the Rivieradal Group is everywhere bounded on its lower surface by the Vandredalen thrust; a stratigraphic base to the group has not been identified within the thrust sheet. The upper boundary of the group is placed where sandstones and laterally equivalent conglomerates are overlain by a characteristic $200 \mathrm{~m}$ variegated unit comprising a 

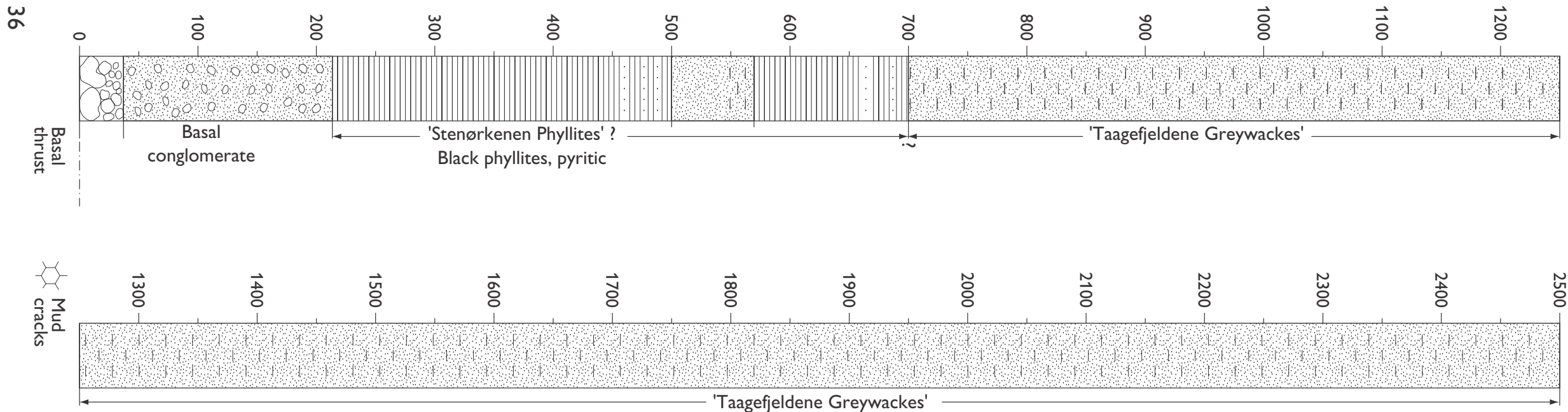

Massive $T_{a, b}$ sandstone turbidites and black pyritic mudstones
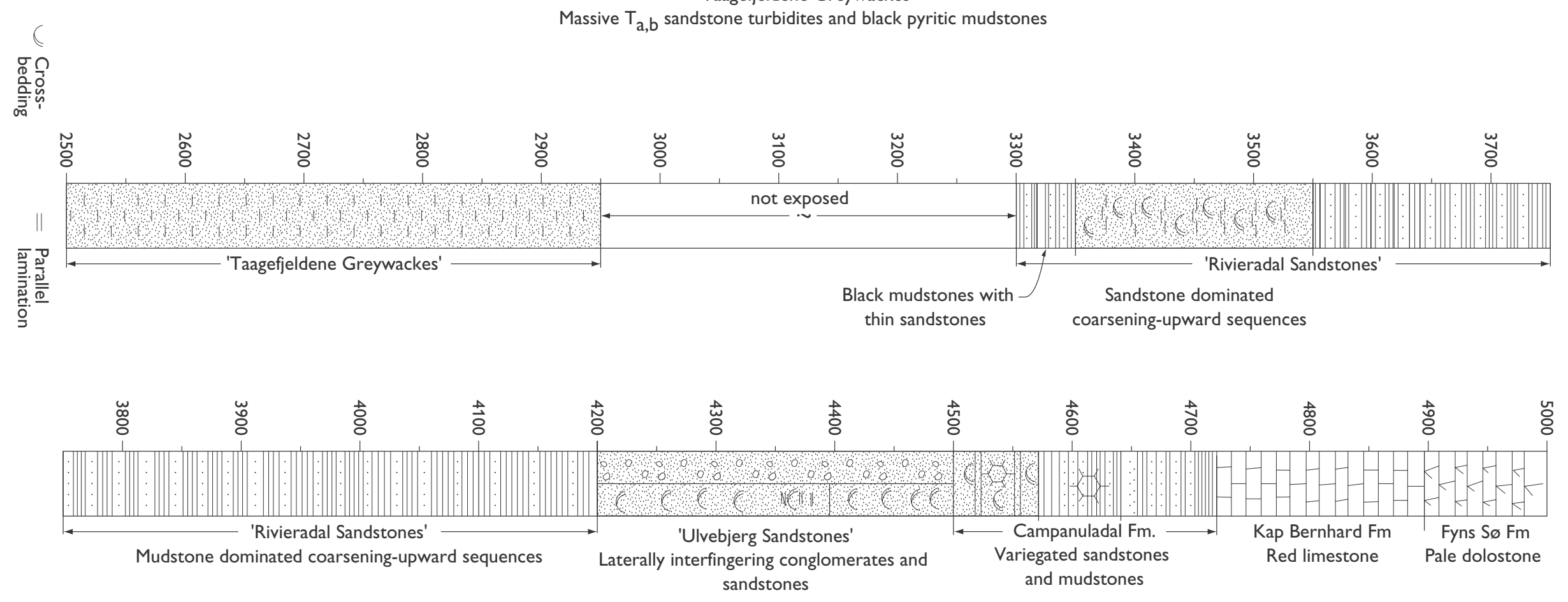
lower greenish sandstone and mudstone interval overlain by a dark red calcareous mudstone-dominated interval. The greenish sandstone and mudstone interval contains parallel and trough cross-laminated sandstones and abundant desiccation cracks. The variegated unit is identified as the Campanuladal Formation of the foreland and, as in the foreland, is overlain by brownish red weathering microbially laminated limestones of the Kap Bernhard Formation (Fig. 4).

Distribution. The Rivieradal Group is restricted to the Vandredalen thrust sheet, and crops out in a broad zone extending from Romer $\$ \varnothing$ southwards along Vandredalen; a further broad zone extends from the eastern end of Centrums $\varnothing$ southwards through Rivieradal and Skallingen to Blåsø (Fig. 1). A narrow strip of outcrops, in the hanging wall of the main thrust ramp, extends from Vardedalen (on the north side of central Ingolf Fjord) southwards to Brede Spærregletscher and along the west side of Hekla Sund to Marmorvigen. The southernmost outcrops of the Rivieradal Group are present in nunataks at the westernmost extremity of Lambert Land (Fig. 1).

Geological age. The group is older than the Hagen Fjord Group, specifically the Kap Bernhard and Fyns Sø Formations, thought to be of probable Riphean age (Smith et al. 1999). However, Frederiksen (2000) has suggested the Hagen Fjord Group is Sturtian, and equivalent to the Andrée Land Group of the Eleonore Bay Supergroup. The Rivieradal Group post-dates the Independence Fjord Group, Midsommers $\varnothing$ Dolerite Formation and Zig-Zag Dal Basalt Formation, all of which are represented by clasts within the conglomeratic units. The dolerites of the Midsommers $\varnothing$ Dolerite Formation were originally dated at c. 1230 Ma by Kalsbeek \& Jepsen (1984), but a recent baddeleyite age on a dolerite of $1380 \mathrm{Ma}$ has been obtained by Upton et al. (in press); this provides a maximum age limit for deposition. The Rivieradal Group was thus deposited in the interval between $1380 \mathrm{Ma}$ and $700 \mathrm{Ma}$.

\section{Facing page:}

Fig. 4. Simplified measured section through part of the synrift Rivieradal Group succession, the lower part in 'Dunkeldal', and the upper part from the west side of Vandredalen. The corresponding lithostratigraphical terms of Fränkl (1955) are indicated. The designation ' $\mathrm{T}_{\mathrm{a}, \mathrm{b}}$ ' refers to Bouma cycle intervals in the sandstone turbidites. The Campanuladal, Kap Bernhard and Fyns $\$ \varnothing$ Formations form part of the post-rift Hagen Fjord Group. Slightly modified from Jepsen \& Sønderholm (1994).
G. Vidal (in Hurst et al. 1985) recorded 'several comparatively well-preserved specimens' of acritarchs from the upper part of the Rivieradal Group which were thought indicative of an upper Proterozoic age. In particular, a single specimen of Chuaria circularis was considered to be indicative of an upper Riphean age since, elsewhere in Scandinavia and North America, the species occurs at around $800 \mathrm{Ma}$. Taken together with the evidence for a conformable upper boundary, this suggests that the Rivieradal Group was deposited in the younger part of the broad age range outlined above.

Subdivision. Fränkl (1954, 1955) recognised five units within the succession now assigned to the Rivieradal Group: 'Stenørkenen Phyllites', 'Sydvejdal Marbles with chloritic shales', 'Taagefjeldene Greywackes' with a layer of alum shales at the base, 'Rivieradal Sandstones', and the 'Ulvebjerg Sandstones and Tillites'.

These units were used as field terms during the 1994-1995 field seasons and proved to be recognisable throughout the area, although this is at least partly because they represent lithological types rather than coherent and homologous stratigraphic units. The 'Stenørkenen Phyllites' are present in Rivieradal and similar phyllites are present throughout the region, although thickness estimates and correlation is hampered by the paucity of marker horizons. Fränkl (1955) estimated a thickness of $>1000 \mathrm{~m}$. The 'Sydvejdal Marbles with chloritic shales' are also present in eastern Rivieradal, and include pelitic and calcareous slates and siltstones with prominent yellow-weathering carbonate units. Fränkl (1955) estimated a thickness of 100-400 m. The 'Taagefjeldene Greywackes' are best seen in the section through 'Dunkeldal' (Fig. 4), where Jepsen \& Sønderholm (1994) recorded a thickness of over 2200 m. This compares with Fränkl's (1954, 1955) estimate of $>700 \mathrm{~m}$, of which 150-200 m were alum shales; multicoloured friable shales cover large areas around the head of Ingolf Fjord, and pass laterally (northwards) along Vandredalen into a sandstonesiltstone-mudstone succession. The 'Rivieradal Sandstones' sensu Fränkl have a thickness of 1400 m, measured in a section across Skallingen for which no base was present (Leslie \& Jepsen 1995), and Jepsen \& Sønderholm (1994) measured a thickness of $900 \mathrm{~m}$ on the western side of Vandredalen (Fig. 4). Fränkl (1954) estimated a range of 1000-2000 m, which appears to be the right order of magnitude. The 'tillites' of Fränkl's (1954, 1955) 'Ulvebjerg Sandstones and Tillites' unit were relatively soon re-interpreted as non-glacial 
conglomerate horizons (Haller 1971; Hurst \& McKerrow 1981a), and they are one of the most spectacular stratigraphic developments within the group. On the western side of Vandredalen, a sandstonedominated unit at least $300 \mathrm{~m}$ thick can be seen to pass laterally into thick conglomerates up to $500 \mathrm{~m}$ thick (Jepsen \& Sønderholm 1994). As noted above, three of these major conglomerate developments are present within the region and represent fan deltas that supplied sediment to the basin.

Although these observations indicate that Fränkl's units may in time form the basis for a stratigraphic framework, any formal definition must await more detailed investigation of the Rivieradal Group.

\section{Acknowledgements}

We are grateful to the referees, L. Clemmensen and J.S. Peel, for their helpful comments.

\section{References}

Adams, P.J. \& Cowie, J.F. 1953: A geological reconnaissance of the region round the inner part of Danmarks Fjord, Northeast Greenland. Meddelelser om Grønland 111(7), 24 pp.

Clemmensen, L.B. \& Jepsen, H.F. 1992: Lithostratigraphy and geological setting of Upper Proterozoic shelf deposits, Hagen Fjord Group, eastern North Greenland. Rapport Grønlands Geologiske Undersøgelse 157, 27 pp.

Fränkl, E. 1954: Vorläufige Mitteilung über die Geologie von Kronprins Christian Land (NE-Grönland). Meddelelser om Grønland 116(2), 85 pp.

Fränkl, E. 1955: Weitere Beiträge zur Geologie von Kronprins Christian Land (NE-Grönland, zwischen $80^{\circ}$ und $80^{\circ} 30^{\prime} \mathrm{N}$ ). Meddelelser om Grønland 103(7), 35 pp.

Frederiksen, K.S. 2000: A Neoproterozoic carbonate ramp and base-of-slope succession, the Andrée Land Group, Eleonore Bay Supergroup, North-East Greenland: sedimentary facies, stratigraphy and basin evolution, 242 pp. Unpublished Ph.D. thesis, University of Copenhagen, Denmark.

Haller, J. 1961: The Carolinides: an orogenic belt of Upper Precambrian age in Northeast Greenland. In: Raasch, G.O. (ed.): Geology of the Arctic 1, 153-159. Toronto: Toronto University Press.

Haller, J. 1971: Geology of the East Greenland Caledonides, 413 pp. London: Interscience.

Higgins, A.K. \& Soper, N.J. 1994: The Caledonian thrust belt of Kronprins Christian Land. In: Henriksen, N. (ed.): Express report: eastern North Greenland and North-East Greenland 1994, 57-67. Unpublished report, Geological Survey of Greenland, Copenhagen.

Higgins, A.K. \& Soper, N.J. 1995: Tectonic and other observa- tions in Vandredalen and adjacent areas of southern Kronprins Christian Land. In: Higgins, A.K. (ed.): Express report: eastern North Greenland and North-East Greenland 1995, 105114. Unpublished report, Geological Survey of Greenland, Copenhagen.

Higgins, A.K., Ineson, J.R., Peel, J.S., Surlyk, F. \& Sønderholm, M. 1991: Lower Palaeozoic Franklinian Basin of North Greenland. In: Peel, J.S. \& Sønderholm, M. (eds): Sedimentary basins of North Greenland. Bulletin Grønlands Geologiske Undersøgelse 160, 71-139.

Higgins, A.K., Leslie, A.G. \& Smith, M.P. 2001a: Neoproterozoic Lower Palaeozoic stratigraphical relationships in the marginal thin-skinned thrust belt of the East Greenland Caledonides: comparisons with the foreland in Scotland. Geological Magazine 138(2), 143-160.

Higgins, A.K., Smith, M.P., Soper, N.J., Leslie, A.G., Rasmussen, J.A. \& Sønderholm, M. 2001b: The Neoproterozoic Hekla Sund Basin, eastern North Greenland: a pre-Iapetan extensional sequence thrust across its rift shoulders during the Caledonian orogeny. Journal of the Geological Society (London) 158, 487-499.

Higgins, A.K., Soper, N.J., Smith, M.P. \& Rasmussen, J.A. 2004: The Caledonian thin-skinned thrust belt of Kronprins Christian Land, eastern North Greenland. In: Higgins, A.K. \& Kalsbeek, F. (eds): East Greenland Caledonides: stratigraphy, structure and geochronology. Geological Survey of Denmark and Greenland Bulletin 6, 41-56 (this volume).

Hurst, J.M. 1984: Upper Ordovician and Silurian carbonate shelf stratigraphy, facies and evolution, eastern North Greenland. Bulletin Grønlands Geologiske Undersøgelse 148, 73 pp.

Hurst, J.M. \& McKerrow, W.S. 1981a: The Caledonian nappes of eastern North Greenland. Nature 290, 772-774.

Hurst, J.M. \& McKerrow, W.S. 1981b: The Caledonian nappes of Kronprins Christian Land, eastern North Greenland. Rapport Grønlands Geologiske Undersøgelse 106, 15-19.

Hurst, J.M., Jepsen, H.F., Kalsbeek, F., McKerrow, W.S. \& Peel, J.S. 1985: Origin of the Caledonian nappes of eastern North Greenland. In: Gee, D.G. \& Sturt, B.A. (eds): The Caledonide orogen: Scandinavia and related areas, 1047-1063. London: John Wiley.

Jepsen, H.F. \& Sønderholm, M. 1994: Sedimentological studies of the Hagen Fjord Group and 'Rivieradal sandstones' (Late Proterozoic), eastern North Greenland. In: Henriksen, N. (ed.): Express report: eastern North Greenland and North-East Greenland 1994, 39-48. Unpublished report, Geological Survey of Greenland, Copenhagen.

Kalsbeek, F. \& Jepsen, H.F. 1984: The Late Proterozoic Zig-Zag Dal Basalt Formation of eastern North Greenland. Journal of Petrology 25, 644-664.

Kalsbeek, F., Nutman, A.P., Escher, J.C., Friderichsen, J.D., Hull, J.M., Jones, K.A. \& Pedersen, S.A.S. 1999: Geochronology of granitic and supracrustal rocks from the northern part of the East Greenland Caledonides: ion microprobe U-Pb zircon ages. Geology of Greenland Survey Bulletin 184, 31-48.

Leslie, A.G. \& Jepsen, H.F. 1995: Tectono-stratigraphic studies of the allochthonous 'Rivieradal sandstones' and Hagen Fjord Group (Late Proterozoic), Kronprins Christian Land, eastern 
North Greenland. In: Higgins, A.K. (ed.): Express report: eastern North Greenland and North-East Greenland 1995, 93103. Unpublished report, Geological Survey of Greenland, Copenhagen.

Pedersen, S.A.S., Craig, L.E., Upton, B.G.J., Rämö, O.T., Jepsen, H.F. \& Kalsbeek, F. 2002: Palaeoproterozoic (1740 Ma) riftrelated volcanism in the Hekla Sund region, eastern North Greenland: field occurrence, geochemistry and tectonic setting. Precambrian Research 114, 327-346.

Rasmussen, J.A. \& Smith, M.P. 1996: Lower Palaeozoic carbonates in eastern North Greenland, and the demise of the 'Sæfaxi Elv nappe’. Bulletin Grønlands Geologiske Undersøgelse 172, 49-54.

Rasmussen, J.A. \& Smith, M.P. 2001: Conodont geothermometry and tectonic overburden in the northernmost East Greenland Caledonides. Geological Magazine 138(6), 687-698.

Smith, M.P., Soper, N.J., Higgins, A.K., Rasmussen, J.A. \& Craig, L.E. 1999: Palaeokarst systems in the Neoproterozoic of east- ern North Greenland in relation to extensional tectonics on the Laurentian margin. Journal of the Geological Society (London) 156, 113-124.

Smith, M.P., Rasmussen, J.A., Robertson, S., Higgins, A.K. \& Leslie, A.G. 2004: Lower Palaeozoic stratigraphy of the East Greenland Caledonides. In: Higgins, A.K. \& Kalsbeek, F. (eds): East Greenland Caledonides: stratigraphy, structure and geochronology. Geological Survey of Denmark and Greenland Bulletin 6, 5-28 (this volume).

Sønderholm, M. \& Jepsen, H.F. 1991: Proterozoic basins of North Greenland. In: Peel, J.S. \& Sønderholm, M. (eds): Sedimentary basins of North Greenland. Bulletin Grønlands Geologiske Undersøgelse 160, 49-69.

Upton, B.G.J., Rämö, O.T., Heaman, L.M., Blichert-Toft, J., Barry, T.L., Kalsbeek, F. \& Jepsen, H.F. in press: The Zig-Zag Dal basalts and associated intrusions of eastern North Greenland: progressive mantle plume - lithosphere interaction. Contributions to Mineralogy and Petrology. 